\title{
The effect of biodegradable nonwoven direct covers on yield and quality of winter leek
}

\author{
Piotr Siwek*, Andrzej Libik, Andrzej Kalisz, Izabela Zawiska \\ Department of Vegetable and Medicinal Plants \\ University of Agriculture in Krakow \\ 29 Listopada 54, 31-425 Kraków, Poland
}

\begin{abstract}
During this two-year experiment (2008-2010), the 'Kenton' leek cultivar was grown in the field from July to March/April of the following year. During the winter months the plants were kept under biodegradable nonwoven covers (Bionolle - polybutylene succinate, 59 and $100 \mathrm{~g} \mathrm{~m}^{-2}$ ). The control treatments were left uncovered. Some cracks and tears in the biodegradable nonwoven covers were observed. The covers resulted in better leek yields. In the first season the bleached parts of the leek contained more ascorbic acid when kept under the Bionolle $100 \mathrm{~g} \mathrm{~m}^{-2}$ cover. The lighter nonwoven $\left(59 \mathrm{~g} \mathrm{~m}^{-2}\right)$ cover caused a grater accumulation of soluble sugars. Biodegradable films, used in the winter cultivation of leek, increased the soil temperature by $1^{\circ} \mathrm{C}$ on average.
\end{abstract}

Key words: Allium porrum, biodegradable materials, Bionolle, row covers

\section{INTRODUCTION}

Plastic covers for the soil and plants have been used in agriculture and horticulture production since the middle of the last century. These are mainly polyethylene films and polypropylene nonwovens, which can be applied in the cultivation of many plants (Briassoulis 2007). A problem with most plastics used in agriculture is the durability of these materials. Their usability ranges from one to 2-4 years, and they take many years to decompose in a temperate climate (Kapanen et al. 2008). Recycling used materials is difficult (Puoci et al. 2008). As reported by Briassoulis (2006), many plastic wastes are either left on the field after production or burnt by the farmers. Thus there is an increasing interest in the use of biodegradable materials that are environmentally friendly (Briassoulis 2006, Wang and Nomura 2010). Investigations of bio- and photo-degradable materials have confirmed their positive effect on crop yields and the ecosystem (Gross and Karla 2002, Moreno et al. 2009, Kasirajan and Ngouajio 2012). An additional aim of these experiments was to find biopolymers that provide optimal conditions for plant cultivation (Moreno and Moreno 2008). To ensure the proper functioning of these materials, they have been tested under real cultivation conditions as well as in the laboratory (Briassoulis 2006, Scarascia-Mugnozza et al. 2006).

In a review article, Kasirajan and Ngouajio (2012) described results from several scientific experiments with polyethylene and biodegradable mulches. Eco-friendly materials are used not only in

\footnotetext{
*Corresponding author.

Tel: +48 1266252 17; fax: +48 124111300 ;

e-mail: psiwek@ogr.ur.krakow.pl (P. Siwek).
} 
crop mulching, but also as low-tunnels (Briassoulis 2004 b, Briassoulis 2006, Kapanen et al. 2008). Films used in low tunnels must be sufficiently durable (Briassoulis 2004 a), while also providing an adequate and homogenous light environment (Scarascia-Mugnozza et al. 2004).

There are several scientific reports confirming the positive effect of direct covers with nonwovens on the yield of vegetable crops, for example watermelon and lettuce (Libik and Siwek 1994) and pickling cucumber (Rumpel 1994). In their review work Olle and Bender (2010) comprehensively described the advantages of direct covers with materials such as polypropylene nonwovens. However, there is a lack of information about biodegradable direct covers. The reason is that these materials are at the experimental stage or their market share is still very small (Briassoulis 2004 a). There are only very few reports about the application of biodegradable covers in horticultural plant cultivation (Siwek et al. 2012). The results obtained in the study showed that using biodegradable nonwovens as direct covers in early butterhead lettuce production affected the yield (positively) and chemical composition of the plants (in different ways).

The aim of the present study was to evaluate the effect of using biodegradable nonwoven covers over the winter on leek yield and quality.

\section{MATERIAL AND METHODS}

Eleven-week-old transplants of frost-resistant 'Kenton' cultivar winter leek were planted (on 22 July 2008 and 3 July 2009) into typical brown soil near Krakow (Poland). The transplants were spaced at $75 \times 15 \mathrm{~cm}$ distance and at a depth $13-15 \mathrm{~cm}$. During the autumn a ridging of the plants (2-3 times) were carried out. Bionolle biodegradable nonwoven (polybutylene succinate) $59 \mathrm{~g} \mathrm{~m}^{-2}$ or $100 \mathrm{~g} \mathrm{~m}^{-2}$ covers were stretched over the leek plants when the air temperature dropped below $0^{\circ} \mathrm{C}$ during the day and before snow (on 22 November 2008 and 11 December 2009, respectively). The covers were kept on until early spring and then removed a few days before harvest (6 April 2009 and 25 March 2010, respectively). This term of harvests allowed us to directly estimate the effect of the biodegradable covers on the yield and growth of the leeks. Plants cultivated without covers served as the control in this study. The experiment was established in randomised blocks with four replications with 20 plants.

Leek was harvested only once each year - on 17 April 2009 and 30 March 2010. At harvest the diameter and length of the bleached parts of leek were measured. Marketable yield (minimal stem diameter $8 \mathrm{~mm}$ ) was estimated according to Polish Norm (PN-R-75521). The biological value of leek was evaluated in the laboratory to assess the ascorbic acid content (Tillman method), dry matter (drying method in $92-95^{\circ} \mathrm{C}$ ) and soluble sugars (anthrone method) (Pinta 1977).

Soil temperature at a depth of $10 \mathrm{~cm}$ was recorded in the non-covered control and Bionolle $59 \mathrm{~g} \mathrm{~m}^{-2}$ using HOBO Temp. sensors (Onset Comp. Corp.) at one hour intervals.

Results were processed statistically using the Newmann-Keuls test, using STATISTICA (data analysis software system, StatSoft Inc.) at a significance level of $\mathrm{p}=0.05$.

\section{RESULTS AND DISCUSSION}

During winter in both years the mean soil temperature at $10 \mathrm{~cm}$ under the biodegradable cover was about $1{ }^{\circ} \mathrm{C}$ higher than at the same depth in uncovered soil (Figs. 1 and 2). In the 2008/09 season when winter was mild with periodical snowing, the mean minimum soil temperature under the cover was $0.6^{\circ} \mathrm{C}$ compared with $0.3^{\circ} \mathrm{C}$ for the non-covered soil. Greater differences in temperature were measured in the 2009/10 season. That year, the mean minimum soil temperature under cover was $-2.2^{\circ} \mathrm{C}$ and $-3.1{ }^{\circ} \mathrm{C}$ for the non-covered soil. The mean maximum soil temperature was $-0.6^{\circ} \mathrm{C}$ and $-1.9^{\circ} \mathrm{C}$, respectively. Polypropylene nonwoven, used as direct covers, is known for increasing soil temperature in comparison to the open field (Olle and Bender 2010). A similar effect was observed in this study for biodegradable nonwoven.

During winter some tearing of the biodegradable covers was observed. Susceptibility to tearing was similar for both tested nonwovens. However, they showed acceptable field life before biodegradation.

In the first year of the experiment the bleached parts were shortest and thicker in the leeks grown under the Bionolle direct cover. No significant differences in diameter were observed in the next year of the experiment, but the longest bleached part was obtained in plants covered with the biodegradable nonwoven (Tab. 1).

There was no significant difference between both weights of biodegradable nonwovens in respect to obtained yields. The expected positive influence was connected with improved overwintering, lower desiccation and better quantity and quality of the yield. The yield obtained from covered leeks was significantly higher in comparison to the control 

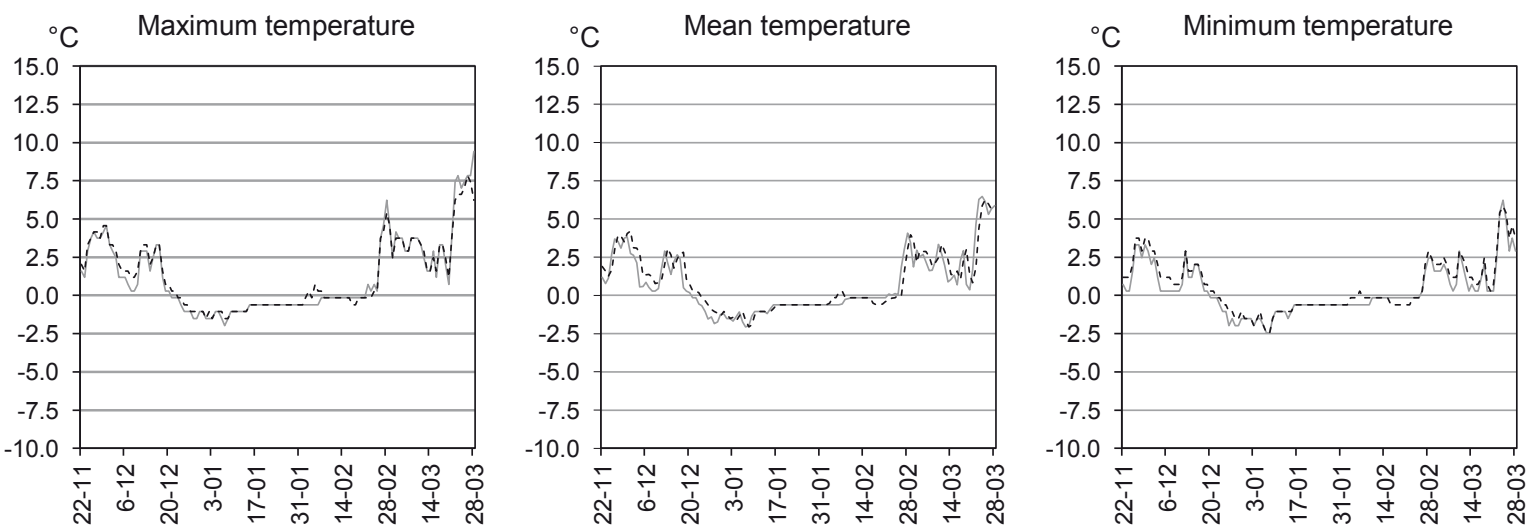

Control Bionolle $59 \mathrm{~g} \mathrm{~m}^{-2}$

Figure 1. Temperature of soil at a depth of $10 \mathrm{~cm}$ during the overwintering of leek under Bionolle (2008/2009)
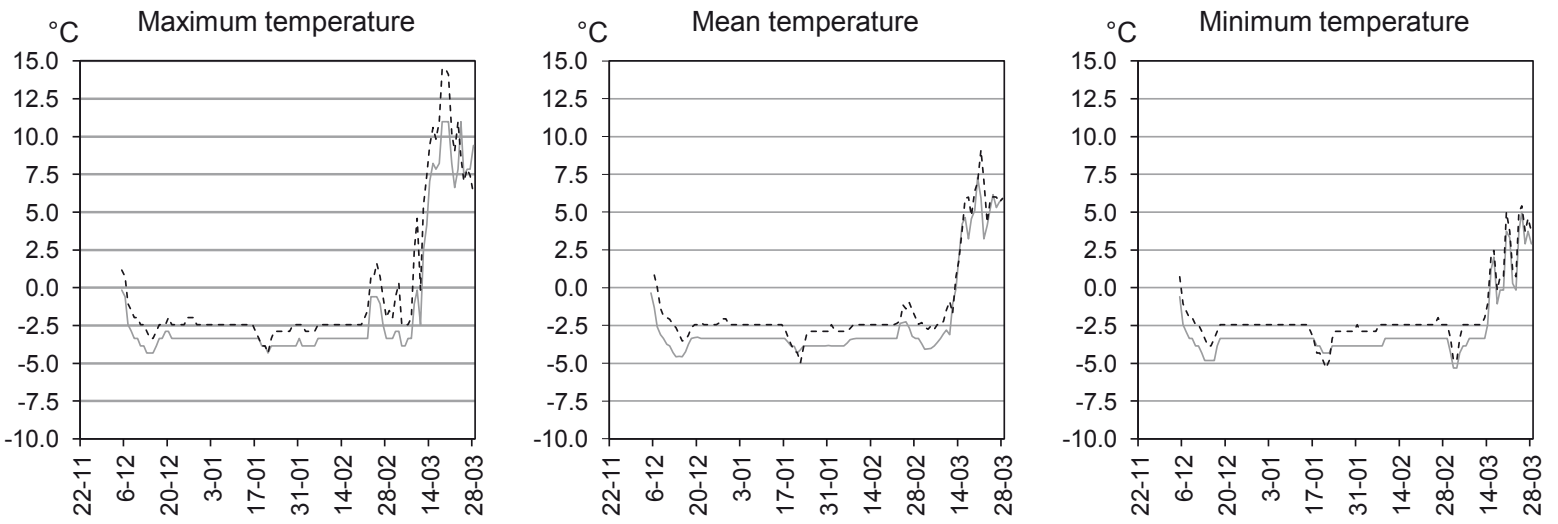

$$
\text { Control -..-.- Bionolle } 59 \mathrm{~g} \mathrm{~m}^{-2}
$$

Figure 2. Temperature of soil at a depth of $10 \mathrm{~cm}$ during the overwintering of leek under Bionolle (2009/2010)

(Tab. 2). In 2009 the difference in marketable yield amounted to $51 \%$, on average, for both thickness of biodegradable nonwovens and in 2010 it was $20 \%$ for nonwoven Bionolle $100 \mathrm{~g} \mathrm{~m}^{-2}$. As far as marketable yield is concerned, the mean values for the two experimental years for the thicker nonwoven (Bionolle $100 \mathrm{~g} \mathrm{~m}^{-2}$ ) were $36 \%$ higher when compared to the control. The total yield in the first year of the experiment was significantly higher as a result of the biodegradable nonwovens.
In the second year, a higher total yield was obtained from plants covered by nonwoven Bionolle $100 \mathrm{~g}$ $\mathrm{m}^{-2}$ in comparison to the control. This good result is the summary effect of higher temperature, a minimisation of wind influence and protection from wildlife (rabbits, birds and roe-deer). Other researchers (Kołota and Adamczewska-Sowińska 2007) have also obtained positive results when overwintering leeks under plastic materials. Yields are usually higher for plants grown under

Table 1. Vegetative growth of 'Kenton' winter leek overwintered under two weights of biodegradable covers

\begin{tabular}{lcccccc}
\hline \multirow{2}{*}{ Kind of cover } & \multicolumn{3}{c}{$\begin{array}{c}\text { Diameter of bleached part } \\
(\mathrm{mm})\end{array}$} & \multicolumn{3}{c}{$\begin{array}{c}\text { Length of bleached part } \\
(\mathrm{cm})\end{array}$} \\
\cline { 2 - 7 } & $17.04 .2009^{*}$ & 30.03 .2010 & mean & 17.04 .2009 & 30.03 .2010 & mean \\
\hline Control & $34.5 \mathrm{a}^{* *}$ & $36.7 \mathrm{a}$ & $35.6 \mathrm{a}$ & $15.2 \mathrm{~b}$ & $15.3 \mathrm{a}$ & $15.2 \mathrm{a}$ \\
Bionolle $\left(59 \mathrm{~g} \mathrm{~m}^{-2}\right)$ & $36.7 \mathrm{~b}$ & $35.3 \mathrm{a}$ & $36.0 \mathrm{a}$ & $12.2 \mathrm{a}$ & $20.0 \mathrm{~b}$ & $16.1 \mathrm{~b}$ \\
Bionolle $\left(100 \mathrm{~g} \mathrm{~m}^{-2}\right)$ & $36.0 \mathrm{~b}$ & $36.0 \mathrm{a}$ & $36.0 \mathrm{a}$ & $12.8 \mathrm{a}$ & $21.3 \mathrm{~b}$ & $17.0 \mathrm{~b}$ \\
\hline
\end{tabular}

*Harvest date

**Mean values marked with the same letters do not differ significantly at $\mathrm{p}=0.05$ 
Table 2. Yield of 'Kenton' winter leek overwintered under two weights of biodegradable covers

\begin{tabular}{lcccccc}
\hline Year & \multicolumn{2}{c}{2009} & \multicolumn{2}{c}{2010} & \multicolumn{2}{c}{ Mean 2009-2010 } \\
\hline Kind of cover & $\begin{array}{c}\text { Marketable } \\
\text { yield } \\
\left(\mathrm{kg} \mathrm{m}^{-2}\right)\end{array}$ & $\begin{array}{c}\text { Total yield } \\
\left(\mathrm{kg} \mathrm{m}^{-2}\right)\end{array}$ & $\begin{array}{c}\text { Marketable } \\
\text { yield } \\
\left(\mathrm{kg} \mathrm{m}^{-2}\right)\end{array}$ & $\begin{array}{c}\text { Total yield } \\
\left(\mathrm{kg} \mathrm{m}^{-2}\right)\end{array}$ & $\begin{array}{c}\text { Marketable } \\
\text { yield } \\
\left(\mathrm{kg} \mathrm{m}^{-2}\right)\end{array}$ & $\begin{array}{c}\text { Total yield } \\
\left(\mathrm{kg} \mathrm{m}^{-2}\right)\end{array}$ \\
\hline Control & $1.15 \mathrm{a}^{*}$ & $1.20 \mathrm{a}$ & $1.87 \mathrm{a}$ & $1.92 \mathrm{a}$ & $1.51 \mathrm{a}$ & $1.56 \mathrm{a}$ \\
Bionolle $\left(59 \mathrm{~g} \mathrm{~m}^{-2}\right)$ & $1.59 \mathrm{~b}$ & $1.68 \mathrm{~b}$ & $1.82 \mathrm{a}$ & $1.87 \mathrm{a}$ & $1.70 \mathrm{~b}$ & $1.77 \mathrm{~b}$ \\
Bionolle $\left(100 \mathrm{~g} \mathrm{~m}^{-2}\right)$ & $1.88 \mathrm{~b}$ & $1.93 \mathrm{~b}$ & $2.25 \mathrm{~b}$ & $2.31 \mathrm{~b}$ & $2.06 \mathrm{~b}$ & $2.12 \mathrm{~b}$ \\
\hline
\end{tabular}

*Explanations: see Table 1

Table 3. The effect of biodegradable nonwoven direct covers used to cover leeks overwinter on ascorbic acid, dry matter and soluble sugar content in 'Kenton' winter leek

\begin{tabular}{|c|c|c|c|c|c|c|c|c|c|}
\hline Year & 2009 & 2010 & Mean & 2009 & 2010 & Mean & 2009 & 2010 & Mean \\
\hline Kind of cover & \multicolumn{3}{|c|}{$\begin{array}{c}\text { Ascorbic acid } \\
\left(\mathrm{mg} 100 \mathrm{~g}^{-1} \text { f.m. }\right)\end{array}$} & \multicolumn{3}{|c|}{$\begin{array}{l}\text { Dry matter } \\
(\% \text { f.m. })\end{array}$} & \multicolumn{3}{|c|}{$\begin{array}{l}\text { Soluble sugars } \\
\text { (\% f.m.) }\end{array}$} \\
\hline Control & $14.5 \mathrm{a}^{*}$ & $12.7 \mathrm{a}$ & $13.6 \mathrm{a}$ & $7.61 \mathrm{a}$ & $9.45 \mathrm{a}$ & $8.53 \mathrm{a}$ & $2.23 \mathrm{~b}$ & $3.31 \mathrm{a}$ & $2.77 \mathrm{a}$ \\
\hline Bionolle $\left(59 \mathrm{~g} \mathrm{~m}^{-2}\right)$ & $14.5 \mathrm{a}$ & $12.6 \mathrm{a}$ & $13.5 \mathrm{a}$ & $7.54 \mathrm{a}$ & $9.98 \mathrm{c}$ & $8.76 \mathrm{a}$ & $2.42 \mathrm{c}$ & $3.84 \mathrm{~b}$ & $3.13 \mathrm{~b}$ \\
\hline Bionolle $\left(100 \mathrm{~g} \mathrm{~m}^{-2}\right)$ & $17.1 \mathrm{~b}$ & $12.5 \mathrm{a}$ & $14.8 \mathrm{~b}$ & $7.73 \mathrm{a}$ & $9.61 \mathrm{~b}$ & $8.67 \mathrm{a}$ & $2.09 \mathrm{a}$ & $3.33 \mathrm{a}$ & $2.71 \mathrm{a}$ \\
\hline
\end{tabular}

*Explanations: see Table 1

polypropylene nonwoven fleece compared to crops in the open field (Olle and Bender 2010). The same result was obtained in the case of butterhead lettuce covered with biodegradable nonwovens (Siwek et al. 2012). Several authors have described comparable or higher yields of crops cultivated on eco-friendly mulches and under eco-friendly lowtunnels (Scarascia-Mugnozza et al. 2004, Minuto et al. 2008) in comparison to standard plastic materials and higher than in the open field control. Thus, the positive effect of biodegradable nonwovens in this respect was also observed in the present experiment.

In both years the ascorbic acid content in the bleached part of the leeks was the highest in leek grown under biodegradable nonwoven Bionolle 100 $\mathrm{g} \mathrm{m}^{-2}$ (17.1 mg $100 \mathrm{~g}^{-1}$ f.m.) (Tab. 3). The difference compared to the control was $2.6 \mathrm{mg} 100 \mathrm{~g}^{-1}$ f.m. In 2010 there were no significant response in the levels of ascorbic acid. Dry matter and soluble sugar content showed no consistent response to the covers treatment. Olle and Bender (2010) concluded that the quality of vegetable plants, regarding their chemical composition, is usually lower under nonwoven fleece in comparison to the control. Moreno et al. (2001) and Acikgoz and Altintas (2011) observed that plants without covers had a higher content of pigments (chlorophylls and carotene) and ascorbic acid. They explained its lower content in covered plants by diminished solar radiation, higher temperatures and relative humidity. However, there are some reports describing opposite results or no significant correlations (Reghin et al. 2002, Kołota and Adamczewska-Sowińska 2007).

\section{CONCLUSIONS}

1. Despite some tearing of covers over the winter, leeks under the biodegradable covers gave higher yields. In the 2008/09 season, the marketable yield was significantly higher for both tested Bionolle covers in comparison to the control, while in the following year this effect was observed for the heavier Bionolle.

2. Due to higher light transmission, leeks covered with the lighter nonwoven had more soluble sugars in comparison to the heavier nonwovens.

3. Biodegradable nonwovens could be used as alternative, more ecological direct covers in comparison to standard materials; however, they should be refined technologically in their durability.

\section{ACKNOWLEDGEMENTS}

The research was supported by a project grant from the Polish Ministry of Science and Higher Education PBZ-MNiSW - 01/02/2007.

\section{REFERENCES}

Acikgoz, F.E., Altintas S., 2011. Seasonal variations in vitamin $\mathrm{C}$ and mineral contents and some yield and quality parameters in komatsuna (Brassica rapa var. pervidis). J. Food Agric. Environ. 9: 289-291. 
BRIASSOULis D., 2004 a. An overview on the mechanical behaviour of biodegradable agricultural films. J. Polym. Environ. 12(2): 65-81.

Briassoulis D., 2004 b. Mechanical design requirements for low tunnel biodegradable and conventional films. Biosyst. Eng. 87(2): 209-223.

Briassoulis D., 2006. Mechanical performance and design criteria of biodegradable low-tunnel films. J. Polym. Environ. 14: 289-307.

Briassoulis D., 2007. Analysis of the mechanical and degradation performances of optimised agricultural biodegradable films. Polym. Degrad. Stabil. 92: 1115-1132.

Gross R.A., Karla B., 2002. Biodegradable polymers for the environment. Science 297: 803-807.

Kapanen A., Schettini E., Vox G., ItävaAra M., 2008. Performance and environmental impact of biodegradable films in agriculture: a field study on protected cultivation. J. Polym. Environ. 16: 109-122.

Kasirajan S., Ngouajio M., 2012. Polyethylene and biodegradable mulches for agricultural applications: a review. Agron. Sustain. Dev. 32: 501-529.

Koєota E., AdamczewsKa-SowińsKa K., 2007. The effects of flat covers on overwintering and nutritional value of leeks. Veg. Crops. Res. Bull. 66: 11-16.

Libik A. Siwek P., 1994. Changes in soil temperature affected by the application of plastics covers field production of lettuce and watermelon. Acta Hortic. 371: 269-273.

Minuto G., Guerini S., Versari M., Pisi L., Tinivella F., Bruzzone C., Pini S., Cappurro M., 2008. Use of biodegradable mulching in vegetable production. $2^{\text {nd }}$ Conf. International Society of Organic Agriculture Research ISOFAR, 16-20 June, Modena, Italy: 35-40.

Moreno D.A., López-Lefebre L.R., Víllora G., Ruiz J.M., Romero L., 2001. Floating row covers affect $\mathrm{Pb}$ and $\mathrm{Cd}$ accumulation and antioxidant status in Chinese cabbage. Sci. Hortic. 89: 83-90.

Moreno M.M., Moreno A., 2008. Effect of different biodegradable and polyethylene mulches on soil properties and production in a tomato crop. Sci. Hortic. 116: 256-263.

Moreno M.M., Moreno A., Mancebo I., 2009. Comparison of different mulch materials in a tomato (Solanum lycopersicum L.) crop. Span. J. Agric. Res. $7(2): 454-464$.

Olle M., Bender I., 2010. The effect of non-woven fleece on the yield and production characteristics of vegetables. Agraarteadus XXX(1): 24-29.

PINTA M., 1977. Absorpcyjna spektrometria atomowa. PWN, Warszawa.
Polish Norm PN-R-75521, 1996. Leek / Pory. Polski Komitet NormalizacyjnyMiar i Jakości, Warszawa.

Puoci F., Iemma F., Spizzirri U.G., Cirillo G., Curcio M., PICCI N., 2008. Polymer in agriculture: a review. Am. J. Agr. Biol. Sci. 3(1): 299-314.

Reghin M.Y., Otto R.F., Vinne J. van der, Feltrin A.L., 2002. Yield of pak choi crop under nonwoven polypropylene. Hort. Brasil. 20(2): 233-236.

RuMPel J., 1994. Plastic and agrotextile covers in pickling cucumber production. Acta Hortic. 371: 253-260.

Scarascia-Mugnozza G., Schettini E., Vox G., 2004. Effects of solar radiation on the radiometric properties of biodegradable films for agricultural applications. Biosyst. Eng. 87: 479-487.

Scarascia-Mugnozza G., Schettini E., Vox G., Malinconico M., Immirzi B., Pagliara S., 2006. Mechanical properties decay and morphological behaviour of biodegradable films for agricultural mulching in real scale experiment. Polym. Degrad. Stabil. 91(11): 2801-2808.

Siwek P., Libik A., Zawiska I., 2012. The effect of biodegradable nonwovens in butterhead lettuce cultivation for early harvest. Folia Hort. 24(2): 161-166.

Wang Q., Nomura C.T., 2010. A survey of biodegradable plastics in the U.S. BioPla. J. 36: 18-23.

\section{WPŁYW OSŁON BEZPOŚREDNICH NA PLONOWANIE I JAKOŚĆ PORÓW ZIMUJĄCYCH}

Streszczenie: W latach 2008-2010 wykonano doświadczenia $\mathrm{z}$ zimującą uprawą porów 'Kenton', których celem była ocena efektywności stosowania włóknin biodegradowalnych $\mathrm{z}$ poliestru alifatycznego Bionolle $\mathrm{w}$ uprawie tego warzywa. Rozsada porów była sadzona w lipcu i zbierana $\mathrm{w}$ marcu/kwietniu następnego roku. W czasie miesięcy zimowych rośliny były przykrywane włókniną Bionolle o masie 59 i 100 $\mathrm{g} \mathrm{m}^{-2}$. Kontrolę stanowiły rośliny nie przykrywane. W czasie zimy były obserwowane na włókninach pęknięcia i uszkodzenia mechaniczne, których przyczyną było obciążenie śniegiem oraz zwierzęta. Osłanianie wpłynęło na lepsze przezimowanie i wyższy plon. W pierwszym sezonie część wybielona roślin przykrywanych włókniną Bionolle 100 $\mathrm{g} \mathrm{m}^{-2}$ zawierała więcej kwasu askorbinowego. Cieńsza włóknina powodowała większą akumulację cukrów rozpuszczalnych. Temperatura gleby pod włókninami była wyższa średnio o $1^{\circ} \mathrm{C}$.

Received October 11, 2012; accepted March 20, 2013 